\title{
TEKNOLOGI SISTEM PLASMA RADIO -FREKUENSI (RF) UNTUK MENGHILANGKAN BAKTERI ESCHERICHIA COLI PADA AIR MINUM
}

\author{
Dean Corio*,Ariadi Hazmi**, Reni Desmiarti*** \\ * Mahasiswa S2 Teknik Elektro Univertsitas Andalas \\ **Staff Pengajar Teknik Elektro Universitas Andalas \\ **Staff Pengajar Teknik Kimia Universitas Bung Hatta
}

\begin{abstract}
Abstrak-Air minum isi ulang merupakan salah satu sumber air minum masyarakat di Indonesia, namun kualitasnya tidak terjamin. Kurang optimalnya alat pengolah air guna menghilangkan polutan produk pada Air Minum Isi Ulang (AMIU), terutama untuk air baku yang mengandung total coliforms maupun fecal coliforms menyebabkan kualitas AMIU tidak terkontrol dengan baik. Penggunaan teknologi plasma radio frekuensi pada sistem pengolahan AMIU bisa dijadikan solusi. Sistem plasma yang terinduksi melalui radio frekuensi pada air dapat membentuk senyawa aktif. Senyawa aktif ini akan bereaksi terhadap mikroorganisme dan menyebabkan mikroorganisme mati. Pada pengujian air limbah $350.000 \mathrm{MPN}$ (100\%), dengan frekuensi plasma 3,3 MHz dapat mendegradasi bakteri sampai $6 \%$ dan dengan settingan frekuensi $3,7 \mathrm{MHz}$ dapat mendegradasi bakteri hingga $0,07 \%$. Pada pengujian air sungai 23.000 MPN (100\%), dengan settingan frekuensi plasma 3,3 MHz dapat mendegradasi bakteri hingga $9 \%$ dan dengan settingan frekuensi $3,7 \mathrm{MHz}$ dapat mendegradasi bakteri hinggaa $6 \%$.
\end{abstract}

Kata kunci : plasma, radio frekuensi, total coliform, fecal coliform.

\begin{abstract}
Refill drinking water is a source of public drinking water in Indonesia, but the quality is not guaranteed. less optimal means of water treatment to remove pollutants in Drinking Water Refill (AMIU), especially for raw water containing total coliforms and fecal coliforms cause AMIU quality is uncontrolled. The use of radio frequency plasma technology on AMIU processing system can be used as a solution. Induced plasma system by radio frequency in water can form the active compound. The active compounds will react to microorganisms and causing microorganisms be reduced. In testing wastewater $35,000 \mathrm{MPN}(100 \%)$, with plasma frequency of 3,3 MHz, the bacteria can degrade to $6 \%$ and with frequency of 3,7 MHz bacteria can degrade to $0,07 \%$. 23.000 MPN testing river water (100\%), with plasma frequency of 3,3 MHz setting can degrade the bacteria to $9 \%$ and with 3,7 $\mathrm{MHz}$ frequency setting can degrade the bacteria to $6 \%$.
\end{abstract}

Keyword : plasma, radio frequency, total coliform, fecal coliform.

\section{PENDAHULUAN}

Masyarakat Indonesia menggunakan air minum isi ulang (AMIU) sebagai sumber air minum, namun kualitas air minum isi ulang ini tidak bisa dijamin (Hazmi, 2012). Selain itu, penggunaan sistem pengolahan bahan baku air minum konvensional seperti sedimentasi, koagulasi-flokulasi, filtrasi dan penggunaan desinfektan seperti klorin, tidak dapat menjamin untuk menghasilkan bahan baku air minum dengan kualitas yang baik sesuai dengan baku mutu yang telah ditetapkan pemerintah (Peraturan Pemerintah No.28 tahun 2001 tentang Standar Baku Mutu untuk Air Baku dan Permenkes RI No.492/ Menkes/ Per/ IV/ 2010 tentang Persyaratan Kualitas Air Minum).
Kurang optimalnya alat pengolah air guna menghilangkan polutan produk pada Air Minum Isi Ulang (AMIU), terutama untuk air baku yang mengandung Total Coliforms maupun Fecal Coliforms yang menyebabkan kualitas air minum isi ulang tidak bisa terkontrol dengan baik. Sistem pengolahan air minum pada depot air minum isi ulang masih mempergunakan karbon aktif untuk menghilangkan bau dan penggunaan klorin sebagai desinfektan untuk membunuh mikroorganisme yang ada dalam air. Karbon aktif memiliki kelemahan, yaitu sulit diregenerasi sehingga diperlukan biaya yang cukup besar untuk mengganti karbon aktif yang baru. Sedangkan klorin merupakan zat kimia 
yang cukup berbahaya bagi kesehatan manusia jika kuantitasnya tidak terkontrol dengan baik.

\section{OBSERVASI}

\subsection{Plasma}

Plasma adalah keadaan benda fase-gas berenergi, yang sering disebut sebagai "keadaan benda keempat" (Fridman, 2008). Plasma terjadi ketika terbentuk percampuran kuasinetral dari elektron, radikal, ion positif dan negative (Gomez, 2008). Kondisi kuasinetral merupakan daerah dimana terdapat kerapatan ion (ni) yang hampir sama dengan kerapatan elektron (ne) sehingga dapat dikatakan ni » ne » $\mathrm{n}$, dengan $\mathrm{n}$ menyatakan kerapatan secara umum yang disebut kerapatan plasma.

Plasma dapat dibuat dengan pemanfaatan tegangan listrik, yaitu dengan menghadapkan dua elektroda di udara bebas (Sun, 1997). Udara adalah isolator, materi yang tidak menghantarkan listrik, namun apabila kedua elektroda tersebut diberikan tegangan listrik yang cukup tinggi, maka sifat konduktor akan muncul pada udara tersebut. Bersamaan dengan itu pula maka tegangan listrik mulai mengalir (electrical dicharge), dimana fenomena ini disebut electrical breakdown (Yanaka, 2009).

Dengan memanfaatkan plasma maka akan didapatkan berbagai macam spesies aktif (active species) seperti $-\mathrm{OH},-\mathrm{O},-\mathrm{H}, \mathrm{O}_{3}$, dan $\mathrm{H}_{2} \mathrm{O}_{2}$ (Kitova, 2009). Hampir dari seluruh spesies aktif ini memiliki oksidasi potensial yang tinggi yang berpotensi dalam menguraikan kandungan senyawa organik di dalam air (Kornev, 1998). Selain dari pada itu plasma dapat menghasilkan sinar ultraviolet serta gelombang kejut (shockwave) yang juga diketahui dapat menguraikan senyawa-senyawa organic (Fridman, 2008).

Fenomena electrical breakdown dalam air umumnya terjadi dari dua fasa yaitu:

a. Fasa prebreakdown atau lebih dikenal dengan streamer discharge,

b. Fasa breakdown atau dikenal dengan spark atau arc discharge.

Bentuk (mode) dari plasma dalam air mempengaruhi efisiensi dari plasma dalam menguraikan senyawa organik yang terkandung dalam air (Sato, 2005). Berdasarkan mode plasma didapati pembentukan hidroksil radikal, radiasi ultraviolet dan gelombang kejut sangat bervariasi.

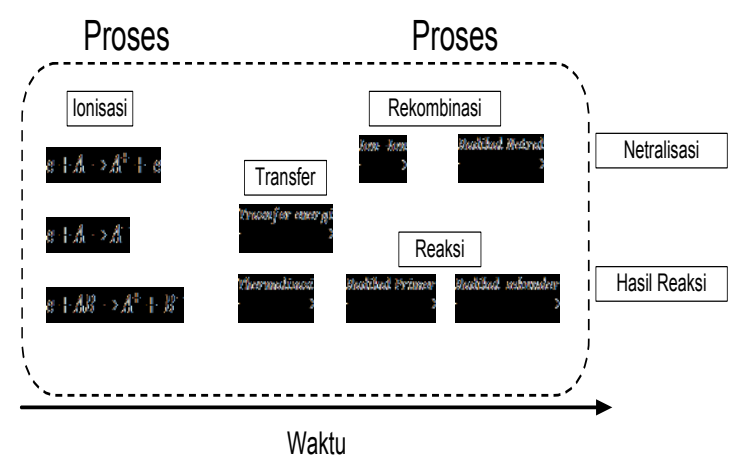

Gambar 2.1. Proses elementer plasma

Ketika medan listrik diinduksikan ke gas, maka elektron energetik akan mentransferkan energinya pada molekul gas melalui proses tumbukan, eksitasi molekul, tangkapan elektron, disosiasi, dan ionisasi yang diperlihatkan pada Gambar 2.1.

\subsection{Radio Frekuensi}

Gelombang radio adalah satu bentuk dari radiasi elektromagnetik, dan terbentuk ketika objek bermuatan listrik dinaikkan frekuensinya pada frekuensi yang terdapat dalam frekuensi gelombang radio (RF) dalam suatu spektrum elektromagnetik (Geveke, 2008)

Radiasi elektromagnetik adalah kombinasi medan listrik dan medan magnet yang berosilasi dan merambat lewat ruang dan membawa energi dari satu tempat ke tempat yang lain (Azharonok, 2011). Gelombang elektromagnetik ditemukan oleh Heinrich Hertz. Setiap muatan listrik yang memiliki percepatan memancarkan radiasi elektromagnetik (Raouf, 1998). Waktu kawat (atau panghantar seperti antena) menghantarkan arus bolak-balik, radiasi elektromagnetik dirambatkan pada frekuensi yang sama dengan arus listrik (Foster, 2000).

Medan listrik dan medan magnet yang dihasilkan akan dimanfaatkan dalam proses plasma, dimana medan magnet akan menyebabkan material logam yang terdapat pada air berada pada sisi kumparan yang dialiri arus listrik (Leal-Quirós, 2007). Sedangkan, medan listrik akan mempengaruhi elektron yang terdapat pada air sehingga terjadi proses ionisasi yang menyebabkan terbentuknya spesies aktif yang akan membunuh bakteri di dalam air (Shirafuji, 2010). 


\subsection{Perhitungan Medan Listrik dan Fluks Elektromagnetik}

Pada Inductive coupled plasma (ICP) dengan menggunakan persamaan Maxwell kita dapat menghitung flux elektromagnetik (S0), dimana;

$S_{0}=9.94 \cdot 10^{-2} \cdot\left(I_{0} n\right)^{2} \sqrt{\frac{f}{\sigma}}$

Dimana;

$$
\begin{aligned}
& \mathrm{S}_{0}=\text { fluk elektromagnetik }\left(\mathrm{W} / \mathrm{cm}^{2}\right) \\
& \mathrm{I}_{0}=\text { arus terukur }(\mathrm{A}) \\
& \mathrm{n}=\text { jumlah lilitan selenoid } \\
& \mathrm{f}=\text { frekuensi }(\mathrm{MHz}) \\
& \sigma=\text { fixed conductivity }\left(\mathrm{ohm}^{-1} \mathrm{~cm}^{-1}\right)
\end{aligned}
$$

Konduktivitas panas plasma sangaat tinggi, dan efek kulit menjaga penembusan medan elektromagnetik (Fridman.2008). Medan listrik plasma per unit panjang dapat dihitung dengan rumus:

$E_{\max }^{2}=\frac{1.51 . P}{a_{w} b_{w}}\left[1-\left(\frac{\lambda}{\lambda_{\text {crit }}}\right)^{2}\right]^{-1 / 2}$

Dimana :

$\mathrm{E}_{\max }=$ medan listrik plasma per unit panjang $(\mathrm{KV} / \mathrm{cm})$

$\mathrm{P}$ adalah daya maksimum $(\mathrm{KW})$

$\lambda$ adalah panjang gelombang

$a_{w}$ dan $b_{w}$ adalah diameter kawat selenoid $(\mathrm{cm})$

Konsep dasar dari induksi plasma adalah induksi elektromagnetik, sehingga pada aplikasinya dapat digunakan untuk tabung yang tidak terguka, atau tidak boleh bersentuhan langsung dengan elektroda.

\section{METODE PENELITIAN}

Pembuatan sistem plasma radio frekuensi ini terdiri dari 3 bagian yaitu; pembuatan catu daya, pembuatan reaktor plasma dan pembuatan penguat dan pembangkit radio frekuensi. Semua komponen ini nantinya di rangkai satu sama lain untuk kemudian diletakkan dalam lemari kaca dengan rancangan sistem batch. Sebelum digunakan pada sampel uji, frekuensi diseting menggunakan varco pada rangkaian dan dikalibrasi dengan frekuensi couter dengan nilai; $3 \mathrm{MHz}, 3,3 \mathrm{MHz}$ dan 3,7 MHz.

Percobaan dilakukan pada dua sampel yaitu sampel limbah selokan selokan 350.000 MPN/100 ml coliform dan 350.000 MPN/100 $\mathrm{ml}$ colitinja dengan frekuensi sistem plasma divariasikan $3 \mathrm{MHz}, 3,3 \mathrm{MHz}$ dan 3,7 MHz; sampel air sungai $23.000 \mathrm{MPN} / 100 \mathrm{ml}$ coliform dan $8.000 \mathrm{MPN} / 100 \mathrm{ml}$ colitinja dengan frekuensi sistem plasma divariasikan $3 \mathrm{MHz}$, 3,3 MHz dan 3,7 MHz. Proses eksperimen untuk melakukan degradasi bakteri escherichia coli yang terdapat dalam sampel percobaan dilakukan di Laboratorium Kimia Organik Teknik Kimia Universitas Bung Hatta. Selengkapnya dapat dilihat pada Gambar 3.1.

Pengukuran arus dan tegangan menggunakan probe yang terhubung dengan osciloscope. Arus dan tegangan serta parameter air diukur dan diuji setiap $(10,20,40,60)$ menit. Air sampel uji yang sudah diradiasi dengan variasi waktu, diukur nilai $\mathrm{pH}$, ORP, EC, TDS dan suhu menggunakan alat analisis digital Martini Mi 180 di Labor Kimia Bung Hatta. Untuk pengujian total coli dan coliform dilakukan di Labkes Padang.

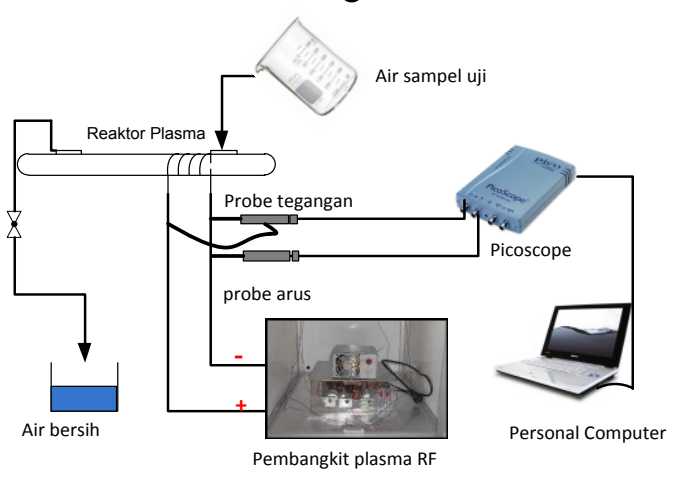

Gambar 3.1. Skema pengolahan air

\section{HASIL DAN PEMBAHSAN}

\subsection{Pengolahan Data}

Hasil pengukuran terhadap sampel air limbah selokan $350.000 \mathrm{MPN} / 100 \mathrm{ml}$ coliform dan air sungai $23.000 \mathrm{MPN} / 100 \mathrm{ml}$ coliform berupa data picoscope diolah dan ditampilkan berupa kurva karakteristik arus dan tegangan, dapat dilihat pada gambar 4.1. Terlihat kencendrungannya, bahwa semakin tinggi frekuensi yang diseting untuk pengolahan air maka semakin tinggi arus dan tegangan yang terukur pada reaktor, hal ini sesuai dengan teorinya dimana kenakian frekuensi menyebabkan kenaikan fluks magnet dan medan listrik. Fluks magnet dan medan listrik sebanding dengan arus. Sehingga dapat disimpulkan bahwa frekuensi sebanding dengan arus dan tegangan sistem. 


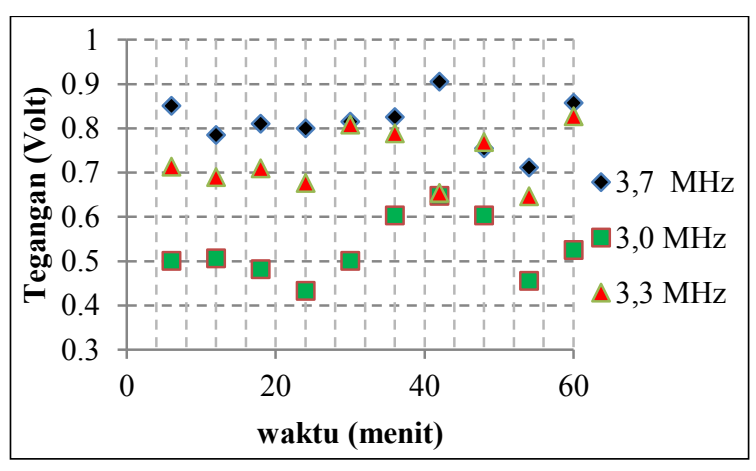

(a)

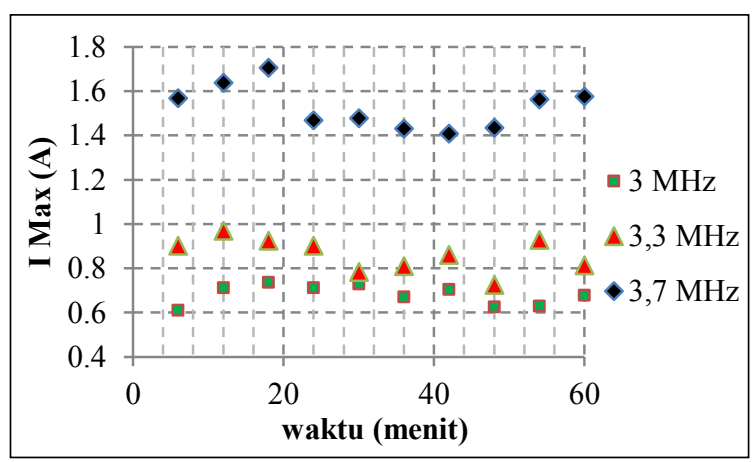

(b)

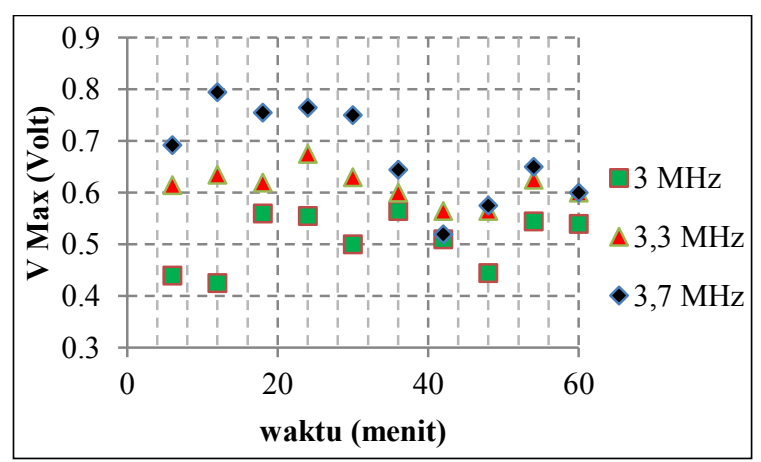

(c)

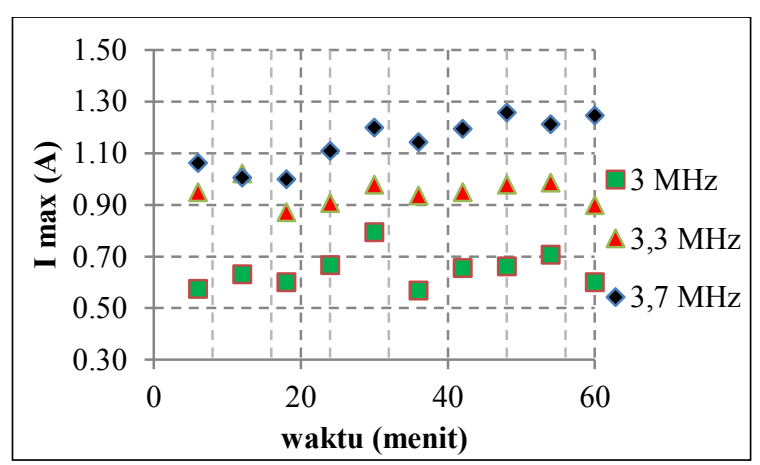

(d)

Gambar 4.1. (a). tegangan maksimum pada sampel uji air limbah $350.000 \mathrm{MPN} / 100 \mathrm{ml}$, (b). arus maksimum pada sampel uji air limbah $350.000 \mathrm{MPN} / 100 \mathrm{ml}$, (c). tegangan maksimum pada sampel uji air sungai 23.000
MPN/ $100 \mathrm{ml}$, (d). arus maksimum pada sampel uji air sungai $23.000 \mathrm{MPN} / 100 \mathrm{ml}$.

\subsection{Penurunan Jumlah Mikroorganisme di dalam Sampel Uji Penelitian}

Setelah dilakukan radiasi terhadap sampel uji selama 60 menit dengan variasi frekuensi, hasilnya diteliti di Labor Kesehatan Padang. Data yang didapatkan di presentasekan terhadap kondisi awal sampel dan dapat dilihat pada gambar 4.2.

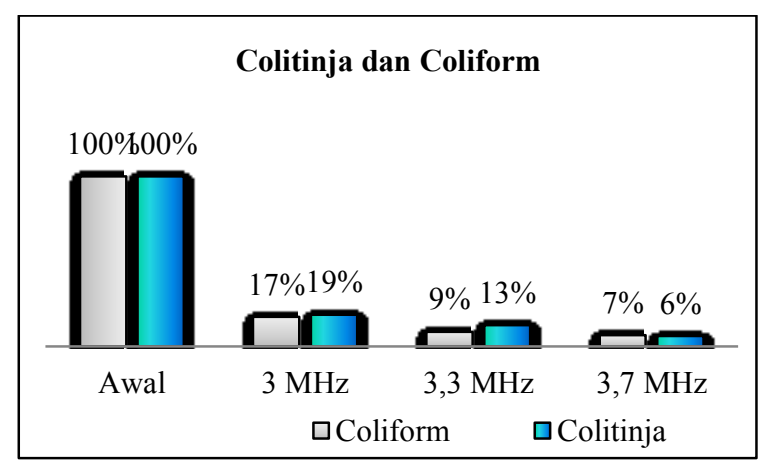

(a)

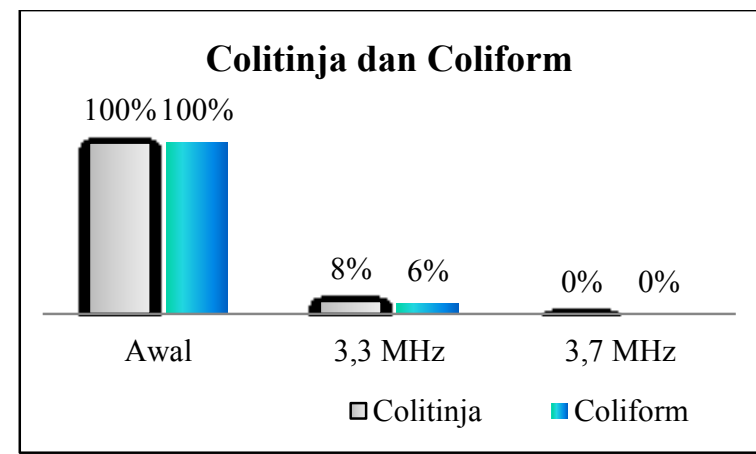

(b)

Gambar 4.2. Total coliform dan colitinja dengan variasi frekuensi untuk sampel (a). Air sungai 23.000 MPN/ $100 \mathrm{ml}$ coliform dan (b) Air limbah selokan 350.000 MPN/ $100 \mathrm{ml}$ coliform

Frekuensi mempercepat terbentuknya plasma dalam tabung reaktor, sehingga semakin besar setingan frekuensi sistem maka akan semakin cepat proses pendegradasian bakteri eschericia coli dalam air sampel uji. Terlihat pada gambar 4.2. dimana dengan frekuensi 3 $\mathrm{MHz}$, bakteri escherichia coli mampu didegradasi hingga $17 \%$ untuk air sungai. Ketika setingan frekuensi dinaikkan menjadi 3,3 MHz bakteri tertinggal dalam sampel hanya $9 \%$ untuk sampel air sungai dan $8 \%$ untuk sampel air limbah, dengan frekuensi 3,7 MHz maka bakteri eschirichia coli tertinggal hanya 7 
$\%$ pada sampel air sungai dan $0,07 \%$ untuk sampel air limbah.

\subsection{Analisa Medan Listrik dan Fluks Magnet}

Medan listrik dan fluks magnet sistem dapat dihitung berdasarkan Persamaan (1) dan (2). Hasil perhitungan secara grafik diperlihatkan pada gambar 4.3.

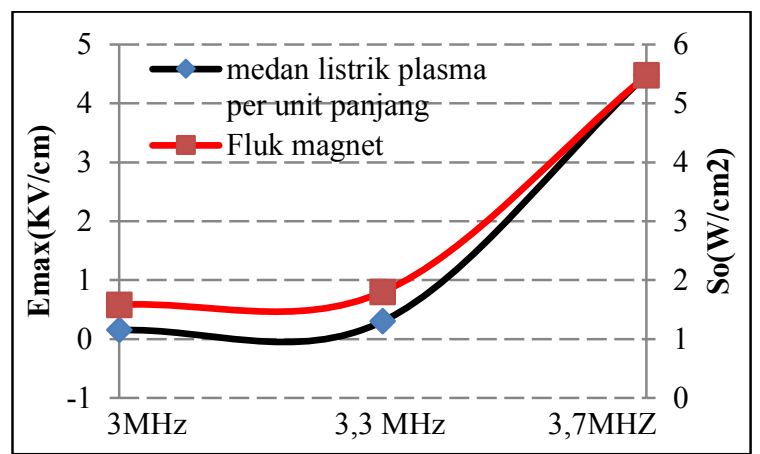

(a)

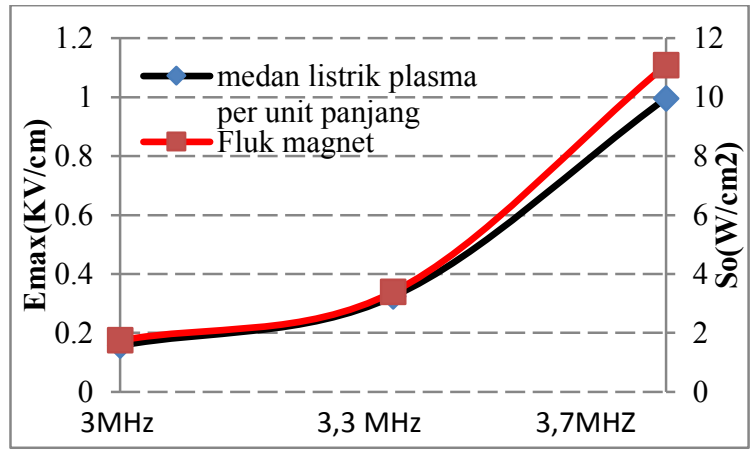

(b)

Gambar 4.3. medan listrik dan fluks magnet dengan variasi frekuensi untuk sampel (a). Air sungai 23.000 MPN/ $100 \mathrm{ml}$ coliform dan (b) Air limbah selokan $350.000 \mathrm{MPN} / 100 \mathrm{ml}$ coliform

Medan magnet berdasarkan persamaan (1) sebanding dengan frekuensi, dimana semakin naik setingan frekuensi sistem maka akan semakin banyak fluks magnet yang terbentuk, fluks akan meradiasi gas dalam reaktor sehingga menjadi spesies aktif (plasma) yang bermanfaat untuk mendegradasi bakteri escherichia coli.

Sedangkan medan listrik berbanding terbalik dengan $\lambda$, sedangkan $\lambda$ merupakan $\mathrm{C} / \mathrm{f}$, dimana $\mathrm{C}$ merupakan kecepatan cahaya dan $\mathrm{f}$ merupakan frekuensi. Sehingga dapat disimpulkan medan listrik sebanding dengan frekuensi. Jadi semakin besar frekuensi sistem maka medan listrik yang terinduksi pada tabung reaktor juga akan semakin besar.

\section{KESIMPULAN}

Kesimpulan yang dapat diambil dari penelitian ini adalah :

1. Sistem radio frekuensi yang digunakan untuk membangkitkan plasma dapat digunakan untuk mendegradasi mikroorganisme didalam pengolahan air minum.

2. Plasma terbentuk lebih cepat bila frekuensi sitem di naikkan, sehingga proses degradasi bakteri yang dilakukan semakin cepat terjadi.

3. Waktu yang dibutuhkan untuk mendegradasi bakteri escherichia coli sebanding frekuensi, dimana semakin besar frekuensi maka waktu yang dibutuhkan untuk menghilangkan bakteri dari air semakin cepat.

4. Pada pengujian air limbah 350.000 MPN (100\%), dengan frekuensi plasma 3,3 MHz dapat mendegradasi bakteri sampai $6 \%$ dan dengan settingan frekuensi $3,7 \mathrm{MHz}$ dapat mendegradasi bakteri hingga 0,07 \%. Pada pengujian air sungai 23.000 MPN (100\%), dengan settingan frekuensi plasma $3,3 \mathrm{MHz}$ dapat mendegradasi bakteri hingga $9 \%$ dan dengan settingan frekuensi $3,7 \mathrm{MHz}$ dapat mendegradasi bakteri hinggaa $6 \%$.

\section{UCAPAN TERIMA KASIH}

Terimakasih atas bantuan dan dukungan berbagai pihak dalam penelitian ini:

- Bantuan dana Tesis LPDP berdasarkan SK Kep-143/LPDP/2013.

- Riset Unggulan Universitas Bung Hatta No.30-22/SP/Hatta-1/LPPM/III/2014.

- Rekan mahasiswa Teknik Kimia Universitas Bung Hatta yang telah membantu dalam proses penelitian.

\section{DAFTAR PUSTAKA}

A.Azharonok, et.all.2011. Non-Thermal Plasma Sterilization In RF And Mw Discharges. Stepanov Institute of Physics NAS. Belarus

Hazmi, Ariadi. 2012. Behavior of Micro organisms Using Radio-Frequency (RF) 
Plasma System. Universitas Andalas: Padang

Edbertho Leal-Quirós, et.all. 2007. An Asses sment of the Power Generated With Plasma Processing of Sludge From Wastewater Treatment Plants. IEEE Transactions On Plasma Science, VOL. 35, NO. 6, December 2007

Foster, Kenneth R. 2000. Thermal and Nonthermal Mechanisms of Interaction of Radio-Frequency Energy with Biological Systems. IEEE Transactions On Plasma Science, VOL. 28, NO. 1, February 2000

Fridman, Alexander. 2008. Plasma Chemistry. Cambridge: USA

Geveke,David J. 2008. Radio frequency electric fields inactivation of Escherichia coli in apple

cider.Elsevier.doi:10.1016/j.jfoodeng.200 7.06.029

Gomez, et.al. 2008.Thermal plasma technology for the treatment of wastes: a critical review.elsevier.doi:10.1016/j.jhazmat.20 08.04.017

Kitova.S. 2009.The Effect of Rf Plasma Treatment on the Surface Activation of Polycarbonate Substrate. Bulgarian Academy of Sciences:Bulgaria

Kornev, Jacob. 1998. Electric Discharge Treatment Of Water Containing Organic Substances. High Voltage Research Institute at Tomsk Polytechnic University.Russia

Masayuki Sato, Anto Tri Sugiarto. 2005. Water Purification Method Using Plasma in Water. Research Center for Calibration Instrumentation and Metrology LIPI, Tangerang.

Raouf,Syahid dan Mark J.kushner. 1998. The effect of radio frequency plasma processing reactor circuitryon plasma characteristics. Universitas illionis: Urbana

Sun B., M. Sato, J. S. Clements. 1997. "Optical Study of Active Species Produced by a Pulsed Streamer Corona Discharge in Water", J. Electrostatics, 39.
Tatsuru Shirafuji, et.all. 2010. FTIR Study of Methylene Blue Plasma Degradation Products through Plasma Treatment on Water.IEEE

Yanaka,Yosaunuri. 2009. Fundamentals and Applications of High-pressure Induction Thermal Plasmas with Coil Current Modulation. Kanazawa University: Jepang

Dean Corio, Lahir di Bukit Gombak Situak, Kabupaten Limapuluh Kota tanggal 22 Juni 1986. Menyelesaikan studi Teknik Elektro di Universitas Andalas tahun 2011 dan menyelesaikan S2 tahun 2014 di Universitas Andalas dengan konsentrasi Teknik Energi Elektrik. 